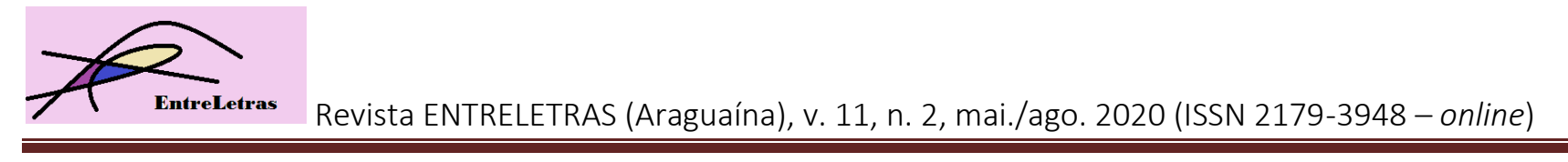

\title{
ESTAR DISPUESTO A ACTUAR: \\ UN ANÁLISIS A LOS ESCRITOS POLÍTICOS DE FRANTZ FANON EN ALIENATION AND FREEDOM
}

\author{
BEING ACTIONAL: \\ AN ANALYSIS TO FRANTZ FANON'S POLITICAL WRITINGS IN ALIENATION AND \\ FREEDOM
}

\author{
Stephanie Mercado - Irizarry ${ }^{1}$
}

Resumen: El presente artículo tiene como objetivo analizar la sección Political Writings del libro Alienation and Freedom, recolección de escritos de Frantz Fanon. El libro es una colección de documentos que fueron parte de un contexto geográfica e históricamente particular afectado por la colonización, pero que fue transformado por acciones anticoloniales. El propósito del presente artículo es el análisis de varios de los escritos políticos de Fanon, con especial énfasis en aquellos publicados en el periódico El Moudjahid. El argumento central es demostrar cómo a través de estos escritos Fanon manifiesta una constancia en lo que fue su pensamiento sobre lo que significa volverse un ser de acción (being actional).

Palabras claves: Frantz Fanon; escritos políticos; descolonización

\begin{abstract}
This article aims to analyze the Political Writings section of the book Alienation and Freedom, a collection of writings by Frantz Fanon. The book is a collection of documents that were part of a geographically and historically particular context affected by colonization, but was transformed by anti-colonial actions. The purpose of this article is the analysis of several of Fanon's political writings, with special emphasis on those published in the newspaper El Moudjahid. My central argument is to demonstrate how through these writings Fanon manifests a constancy in his thought about what it means to become actional.
\end{abstract}

Keywords: Frantz Fanon; political writings; decolonization

"This epopee of the New World - its sufferings, its humanity - for you, dear Houria, on this first day of the grand Algerian state. Hope! Hope! Éd."-Édouard Glissant ${ }^{2}$

\footnotetext{
${ }^{1}$ Estudiante doctoral del Departamento de Literaturas, Culturas y Lenguajes en la Universidad de Connecticut (UCONN), Estados Unidos. E-mail: stephanie.mercado-irizarry@uconn.edu

${ }^{2}$ Dedicatoria de parte de Édouard Glissant, en la copia de Les Indes. Poème de l'une et l'autre terre, encontrada en la biblioteca de Frantz Fanon. Tomado de la sección Frantz Fanon's Library, en Alienation and Freedom, p. 735.
} 


\section{Introducción}

Este ensayo analiza la sección Political Writings del libro Alienation and Freedom, recolección reciente de los escritos de Frantz Fanon. Dicha colección, editada por Jean Khalfa y Robert J. C. Young y traducida al inglés por Steven Corcoran, es en esencia un archivo de documentos nunca antes publicados o documentados a los cuales el público en general tendría difícil acceso si no fuese por ediciones como esta. El propósito pues, de este ensayo, es demostrar cómo a través de estos escritos, Fanon manifiesta una constancia en su pensamiento sobre lo que significaba volverse un ser de acción (being actional $\left.^{3}\right)^{4}$; alguien que estuviera dispuesto a actuar, así como algunas vías posibles para crear una nueva humanidad. Particularmente me enfocaré en los artículos escritos por Fanon en el periódico El Moudjahid. Para llevar a cabo este análisis, partiré desde el estudio de varios académicos expertos en Fanon; entre ellos, los escritos de Nigel Gibson \& Roberto Beneduce, Lewis Gordon, Jane Anna Gordon y Nelson Maldonado Torres.

\section{Análisis}

En la introducción de Political Writings, tercera parte del libro y escrita por Khalfa, se señala que en estos escritos se puede ver la evolución constante del pensamiento de Fanon, al mismo tiempo que su fidelidad por las orientaciones de ese propio pensamiento. Particularmente, estos artículos que aparecieron en el periódico El Moudjahid escaseaban (y aún hoy día) al acceso de lectores. Este periódico es la edición francesa publicada por el Frente de Liberación Nacional (FLN), frente al cual todos sabemos, Fanon pertenecía. Fanon colaboró activa y anónimamente en la edición de este periódico entre los años 1957 al 1960. Por cierto, como los textos eran anónimos y el periódico era escrito de modo colectivo, algunos de los que participaron en dicho grupo se dieron a la tarea de descifrar y señalar cuáles fueron los textos escritos por Fanon. Uno de estos miembros fue Rédha Malek, editor en jefe para la fecha en que Fanon participó activamente de los escritos. En una carta que data del 14 de septiembre de 1963 a François Maspero, quien se dedicó a recopilar estos y otros trabajos políticos de Fanon, Malek comenta:

\footnotetext{
${ }^{3}$ Black Skin, White Masks. Traducido por C.L. Markmann. Grove Press, 1968.

${ }^{4}$ A pesar de varios intentos por conseguir una posible traducción al español del término actional (being actional) decido hacer uso de la siguiente, la cual surgió en una conversación con el filósofo Nelson Maldonado Torres, quien me sugirió dos opciones, y cito: “Adquirir la capacidad para actuar; o convertirse en alguien que está dispuestx [sic] a actuar. [Ambas traducciones] pueden variar; depende de la estructura de la oración y del contexto.”
} 
As El Moudjahid's chief editor from July 1957 to August 1962, I am quite capable of determining exactly the contribution of this or that writer. El Moudjahid was the work of a team that always worked together and in anonymity. The most important topics dealt with in it were conceived, and I would even say, thought through, jointly. This explains somewhat the discomfort I feel faced with your editorial project, which naturally runs counter to that anonymity, which we had respected until the end.... I will ask you to emphasize, in the preface for example, that El Moudjahid is the work of an anonymous team of which Fanon was an integral part and that the publication of these articles by him as such constitutes a rather exceptional event, given the rule to which this team had remained steadfast - at least until the cease fire. So, in my view, what ought perhaps to be highlighted - and my friend Claude Lanzmann is well placed to do so - is the decisive influence of the Algerian revolution on Fanon's thinking. Les Damnés de la terre is basically a development and deepening of topics that are treated in El Moudjahid, and that were elaborated from day to day by our editorial board (notably topics concerning the dialectical relations between the, total character of oppression and the no less total character of struggle, between the war of liberation and the transformation of collective awareness, etc.). There can be no question of reducing Fanon's personal contribution in any way, the point is to situate him in the concrete context in which he so marvellously integrated himself (FANON, 2018, p. 534-535).

Los artículos se presentan en esta sección de manera cronológica, en donde se redescubre la insistencia y el interés de Fanon por el resquebrajamiento de las figuras y estructuras opresoras. A diferencia de Khalfa, quien señala que en estos artículos se ve un interés en Fanon por recomendar una liberación de las identidades del pasado (FANON, 2018, p. 535), sugiero que más que una liberación del pasado, es la creación de nuevos espacios, ideas y acciones a través de las experiencias de esas identidades. Aun así, concuerdo con el editor en que, en todo caso, la lectura de estos textos nos permite revivir y acaso repasar la atmósfera que llevó a Fanon a culminar el libro Los condenados de la tierra.

Como menciona Lewis Gordon en su libro What Fanon Said, Fanon no nos ofrecía un retrato romántico del colonialismo y de la lucha en contra de éste (GORDON, 2015, p.123), sino al contrario: que el colonialismo es un sistema que perpetúa la violencia, y este dato queda demostrado en estos artículos. La violencia de Francia hacia Argelia queda descrita en casi todos los artículos; el propósito de estos escritos era evidenciar y explicar el propio uso de la violencia de parte de los frentes argelinos para llevar a cabo los procesos de descolonización. De acuerdo con Gibson y Beneduce, en Los condenados de la tierra (1963) Fanon utiliza el término de desintoxicación ${ }^{5}$ para referirse a que, a nivel individual, la violencia es una fuerza que limpia ("Au

\footnotetext{
${ }^{5}$ Traducción propia
} 
niveau des individus, la violence désintoxique") (GIBSON; BENEDUCE, 2017, p. 6). El legado colonialista es tóxico, y por ende, se necesita de un proceso que desintoxique, que de paso a la liberación en todos los aspectos: esto es la descolonización. En estos artículos, Fanon señala que la descolonización es un proceso -que como sabemos, muchas veces es visto como una finalidad, y no un principio- y por ello es siempre violenta.

La violencia no es una solución simple. Para Fanon, era una contradicción dialéctica y necesaria que contiene una dualidad, que sería una reacción natural hacia la propia violencia colonial; aun así, se entiende que la violencia es problemática, y que no será suficiente para liberarse de todo el legado de dominación colonial (GIBSON; BENEDUCE, 2017, p. 8). En el segundo artículo de la sección, Algeria's Independence: an everyday reality, Fanon señala que

the extreme form that French colonialism assumed in Algeria - settlement colonialism of a southern type - has elicited no less extreme reactions in the people. These cannot be reduced to bouts of collective violence or uncontrolled movements of revolt and despair. They are translating into a slow maturation of political awareness, which they broaden in contributing to it a revolutionary dimension (FANON, 2018, p. 552).

Todo tipo de acto que atente en contra de las imposiciones establecidas dentro del estatus quo, será visto como uno violento e incluso monstruoso. Este tipo de acto violento que puede ser visto como atroz de parte de ciertas estructuras dentro del ideal hegemónico, es una consecuencia de un sistema que tiene como eje la explotación y la deshumanización. En su libro Creolizing Political Theory: Reading Rousseau through Fanon, Jane Anna Gordon señala que para Fanon no hay alternativa alguna para apoderarse de la libertad de uno, excepto que sea a través de la lucha en defensa propia por la dignidad, la cual ha sido fuertemente desafiada, pero que aun así las consecuencias son inescapablemente trágicas (GORDON, 2014, p. 142).

El enfoque primordial de Fanon en estos artículos es revelar la realidad de la violencia estructural en una sociedad colonizada, así como los diversos mecanismos que retaron el uso de esta violencia. Estos actos desafiaron de tal forma que quedan como un ejemplo de una legítima dispensación de fuerza. A pesar de ser vistos como actos monstruosos, incluso pudiesen ser catalogados como "luchas democráticas," ya que se nivela contra la falta de libertad, "uncovering structural inequalities, seeking to broaden who constitutes the polity so that it better reflects all implicated, even if this will require ridding it of those most committed to maintaining oppressive conditions (GORDON 2014, p. 134). El argumento sería entonces en que es inútil llevar a cabo 
actos no violentos cuando se busca un cambio en la estructura social, ya que como mencioné anteriormente, todo acto que atente en contra del sistema es considerado violencia. Esto es, por la presunción que existe de que dicho sistema es uno justo. Lewis Gordon señala que por ende surge la siguiente interrogante: ¿Por qué entonces cambiar un sistema que, a sabiendas de todos, es justo?:

Colonization reaches not only epistemic levels (colonization of thought) but also moral ones (the idea of maintaining colonialism on moral grounds). Preserving colonialism as a moral enterprise jeopardizes the legitimacy of morality for those committed to eliminating colonialism (GORDON, 2015, p. 23).

Esa monstruosidad expuesta en los escritos de Fanon pudiese ser catalogada como una inmoral, pero es dentro de esta supuesta inmoralidad que muchas veces se dan transformaciones sociales.

\section{Lucidez a través de la acción: el paso para una conciencia política}

El tercer artículo de esta sección de escritos políticos es National independence: the only possible outcome; creo que este artículo es uno de los más importantes de la tercera parte de Alienation and Freedom, ya que en éste se encuentran los diversos temas que más le preocupaban a Fanon, tales como el uso de la violencia, la lucidez en los colonizados, y los diversos pasos que se pudiesen dar hacia la transformación o el devenir de una nueva humanidad. Fanon entiende que a través del redescubrimiento de nuevas personalidades que se dan a través de la acción por la lucha de la descolonización, es que surgen nuevas posibilidades: esto es lo que considera como un "nuevo hombre"

\footnotetext{
From the Algerian of the colonial period, a new man has sprung, the Algerian of the era of independence. This Algerian rediscovers his personality in action, discipline, the sense of responsibilities, and rediscovers the real that he takes fully in hand and transforms by renewing efficient relations with it. He becomes a responsible citizen, an organizer, an administrator and a soldier (FANON, 2018, p. 554).
}

Debo señalar que cuando Fanon se refiere a un "nuevo hombre", es que apunta a un nuevo sujeto que surge a través del proyecto de liberación. En este pasaje Fanon argumenta que un nuevo sujeto ha surgido, uno que se redescubre a través de la acción y transformación mediante las relaciones que se dan dentro de los espacios en los que se encuentra; este actor, o actores, son los 
que eventualmente denominara como los condenados de la tierra. A raíz de esta visión, que queda expuesta por igual en Piel negra, máscaras blancas, de acuerdo con Nelson Maldonado Torres, el rol de Fanon pasa a convertirse en una "catalytic formula whose function resides in enabling the possibility of proper agency" (MALDONADO TORRES, 2005, p. 158). Para Maldonado Torres, el rol del analista no es de decir a "ciencia cierta" cuál es la propuesta para llevar a cabo el proyecto de liberación, sino que habilita la posibilidad para que se dé la propuesta desde el "nuevo hombre".

Ahora bien, parece ser que Fanon pudiese incluso representar en cierto modo ese mismo "nuevo hombre" que propone. De acuerdo con Jane Gordon, Fanon se declara "irreductiblemente" un hombre de su tiempo. Gordon señala que Fanon,

Rather than always being the foreigner, writing from elsewhere, to the dismay of some and delight of others, he made the places to which he moved his own. Not only through identifications expressed in descriptions of himself as the Martinican-Algerian revolutionary psychologist and philosopher, he also took direct responsibility for and put his manifold insights and skills in the service of what his new homes would become. (GORDON, 2014, p. 165)

Gordon aquí hace referencia a ese nuevo lugar al que Fanon luego perteneció, así como también trae a colación su "origen", o las formas en que Fanon se identificaba: un psicólogo antillano, un filósofo argelino... un revolucionario. Es pertinente esta observación de Gordon, ya que aquí queda plasmada la idea de lo que Fanon proponía cuando nos hablaba de la nueva humanidad o del "nuevo hombre". A través de estos escritos políticos, Fanon demuestra la constancia en su idea de que a través de una mezcla combinada de ciertos elementos -como las particularidades de las subjetividades de los colonizados y aquellas del imperio-pueden surgir cambios radicales que den paso a la liberación. En el escrito At Conakry, he declares: 'Global peace goes via national independence', Fanon escribe que la victoria argelina no sólo será de Argelia, sino que también será una victoria africana y asiática en donde se conflagra una lucha que el frente argelino ha intentado concluir para darle espacio a ese "nuevo hombre" en Argelia. Fanon considera que el ejército "encounters the enthusiastic support of world opinion" y que el ejército "is a force to be reckoned with. The Algerian government proposes to the French government that they find a solution together so that no more blood is split" (FANON, 2018, p. 642). Esto que Fanon apunta aquí es clave para comprender su idea de lo que él sostiene que es lo necesario para volverse un ser actional, ese ser que está “dispuesto a actuar." Siguiendo el análisis de Maldonado Torres, considero que ese señalamiento de Fanon en que el ejército argelino busca una solución en conjunto 
con el ejército francés, sugiere que el sujeto argelino ha encontrado la capacidad para dar paso a un entendimiento mutuo, crucial para dar paso a otras posibilidades.

En el sexto artículo, A democratic revolution también hace mención de esa transformación desde el individuo argelino y su comunidad, esta vez explicando que las particularidades históricas de este colectivo (su historia precolonial y la adquisición de algunos valores modernos) es lo que los llevará a liberarse:

This twofold exigency means that the Algerian people is at once the most nationalist and the most open, the most faithful to Islam and also the most welcoming of extra-Islamic values. Of Muslim peoples, it is perhaps one of the most attached to the Muslim faith and one of the most steeped in the spirit of the modern west. Hence, faced with destructive colonialism, the most natural reaction of the Algerian people has been the patient assimilation of modern technological values. So, the notion of democracy is not foreign to it; the values that have provided for the blossoming of the individual, and without which no progress is possible - it has made them its own and attaches to them all even greater worth for having been deprived of them (FANON, 2018, p. 572).

Aquí Fanon nos señala que, a raíz del contexto colonial, los argelinos conocen sus propios valores culturales y religiosos, así como también conocen esos valores impuestos por las ideas de Occidente, y que, al conocerlos, los han hecho propios y les otorgan un valor aún mayor que otras sociedades, debido a que han sido privados de ellos. Este tipo de análisis de Fanon nos apunta a esa creolización a la que Jane Anna Gordon se refiere cuando nos comenta que la creolización nos ofrece un modelo de cómo las personas han construido mundos colectivos a partir de la necesidad, y que no es a través de pequeñas partes no asociadas que coexistan en una hostilidad mutua, sino reconociendo, explorando y enunciando interdependencias complejas en formas que se codifican e incorporan de manera que cada una se comprenda en y a través de los términos de cada una, para que las condiciones de inteligibilidad y socialidad mutuas puedan emerger (GORDON, 2014, p. 196). Así también, podemos secundar esta afirmación desde el análisis de Lewis Gordon cuando comenta

Although the specific words of the supposedly premodern moment may persist, their meaning is advanced in a peculiarly modern set of relations. [T] hey have been transformed through the unique historical situation to which they have been applied over the past several hundred years to make sense of what was happening to the communities in which they were originally articulated. The result, then, is a question of decolonization and transformation at the normative level, as Fanon hinted in his critique of Greco-Latinism. Not only are new concepts being formed in the Global South but also possibly new norms (GORDON, 2015, p. 129). 
Así, se demuestra este proceso en estos escritos, de esa articulación que tiene como base formas complejas que son interrumpidas, adaptas y recreadas para crear otras alternativas que den paso a eso que Fanon cataloga como una nueva humanidad. De acuerdo con Gibson y Beneduce, Fanon adoptó este concepto que representa una liberación total que

finds expression in the assertion of dignity and humanity emerging in and from the struggles against racism and colonial dehumanization. At the same time, he warned that "we must not expect the nation to produce new men and new women [who] change imperceptibly as the revolution constantly innovates. It is true that both processes are important, but it is consciousness that needs help" (GIBSON; BENEDUCE, 2017, p. 10).

Esta idea de la nueva humanidad a través de la lucha por la liberación aparece reiteradamente en el octavo artículo, Algerian revolutionary consciousness. Aquí Fanon expone la idea de una nueva generación a través de la lucha argelina:

The Algerian people's fight, conducted with such enthusiasm and tenacity, acquires its real meaning not only in relation to French colonialism, whose end it must bring about, but more profoundly still in relation to Algeria's entire history, which this fight is summoned to transform and rebuild on new bases. The process of national liberation in Algeria is too deep not to take the character of a revolutionary process that increases the vigour of the anticolonialist struggle and that opens up prospects for a substantial change apt to turn the people's destiny upside down (FANON, 2018, p. 582).

Invertir el destino. Volcarlo. Crear un nuevo comienzo a través de nuevos tipos de pensamiento y de acción. Una sociedad como la argelina, que ha padecido de los estragos del colonialismo francés, pero que a su vez tiene su propia historia, es capaz de poner tanto la cultura imperial como la suya a confrontarse, de modo tal que en este diálogo se enriquecen mutuamente. En otras palabras, tanto la cultura de los argelinos como la del colonizador colapsan. En el punto en que los colonizados no ven que hay futuro solo con sus actitudes y acciones pensando en el pasado, deciden rescatar y dialogar con aquellos valores que representen lo mejor de cada una de las culturas con las cuales se han inmiscuido. Esto es lo que significa ser actional. En palabras de Gordon, "no hay respeto recíproco sin antes haber confrontamiento" (GORDON, 2015, p. 91). Por ello es importante entender la necesidad de la violencia, y de lo que significa para el sistema llevar a cabo actos transgresores: 
Set in motion, they break with the structures that had kept them riveted to their immobility and passivity; they trigger the collapse of the system of oppression, reducing it to dust. Within this gigantic movement they become aware of themselves, of their strength and their creative capacity finds the means of its realization (FANON, 2018, p. 582).

Al final del artículo, Fanon señala la necesidad de la revolución para acabar con las estructuras arcaicas "congeladas" (frozen feudal and patriarcal structures), estáticas; la idea de traer un movimiento de las masas para conquistar la libertad. A pesar de que la libertad de uno la puede controlar otro, es la lucha por la liberación lo que realmente engendra la libertad propia. De acuerdo con su planteamiento, estar activamente envuelto en estas luchas es saludable.

Por otra parte, Fanon demuestra esa "conversión" de alguien que está dispuesto a actuar en Algeria's independence: an everyday reality. Aquí argumenta que la ignorancia de las vidas argelinas por parte de los franceses y de aquello que no encaje dentro de sus concepciones legítimas, es relegado a la zona del no-ser. Esta ignorancia de su existencia es lo que llevó a los franceses a tener "vanas esperanzas" de que las demandas argelinas podían ser "suavizadas;" los franceses pasaron por alto la autonomía que se iba forjando con las acciones cotidianas del pueblo argelino:

Sovereignty is one and indivisible: our stance on this point is unwavering because it has emerged from the very exercise of this sovereignty. Day by day, the Algerian citizen works towards establishing the state on the territory and strengthening it in decisive fashion. Each ambush, each act of solidarity, each decision taken in the name of the National Liberation Front and Army works to bolster the revolution's authority and to attest to its prodigious vitality. In return, the revolution's blossoming sheds light on the combatant's action by placing him in direct communication with the nation (FANON, 2018, p. 548).

Concuerdo con la nota al calce de los editores en esta página en Alienation and Freedom, en donde señalan que este mismo vocabulario y tono son discernibles en muchos de los textos escritos de Fanon. De acuerdo con ellos, para Fanon, ganar la autonomía aún a través de la participación más básica o simbólica (pero auténtica), y de la realidad diaria, creará los nuevos sujetos de la nación. Lo importante será que los sujetos adquieran la capacidad de actuar o se conviertan en seres dispuestos a actuar.

Por último, cabe señalar que como mencioné anteriormente, Fanon bien pudiese representar a ese "nuevo hombre" plasmado en estos escritos, y a pesar de ser artículos anónimos en un principio, considero que representan en sí a la propia sociedad argelina y cómo se iba desarrollando en ese espacio histórico. Entiendo que, incluso para comprender desde un modo de instrucción 
estos escritos políticos, pudiese considerarse el señalamiento de Maldonado Torres, quien sugiere que Fanon se vuelve una especie de pedagogo que "aims to facilitate the formation of subjectivity, self-reflection, and the praxis of liberation. And it is precisely in enabling the sub-other to take a position in which he or she can recognize and do things for himself or herself -that is, to act" (MALDONADO TORRES, 2005, p. 159). De acuerdo con Maldonado Torres, esto que Fanon busca lo hace debido a que él reconoce lo que posiblemente conlleva forjar una estructura social humana a partir del poder de los que han sido sometidos por diversas estructuras jerárquicas de opresión. Sostengo pues, que en esta sección, Political Writings, Fanon nos muestra una antesala al futuro de su obra: comprender el efecto de la colonización europea tanto en África como el Caribe, y de paso, transformar la humanidad a partir de esta comprensión, tal como señalara en su última obra, Los condenados de la tierra.

\section{Conclusión}

Estos escritos políticos pueden ser catalogados como parte de ese gran esfuerzo que "rehabilita al humano." Quizás las ideas de Fanon pueden sonar "idealistas" para algunos, pero concuerdo con Gibson y Beneduce en que es un esfuerzo que toma tiempo, particularmente en cuanto a la construcción de la confianza en aquellos y aquellas que han sido explotados y deshumanizados. Pero tal como arguyen, esta posibilidad dependería de un forjamiento de nuevas relaciones y nuevas actitudes "as they uncovered the talents and developed through struggle that would enable them to make the leap into a new stage of freedom" (GIBSON; BENEDUCE, 2017, p. 10). De acuerdo con su planteamiento fanoniano, habría que ser y actuar en la historia. Los escritos en el periódico El Moudjahid fueron parte de un contexto geográfica e históricamente particular, de un espacio que fue afectado profundamente por la colonización, pero que al mismo tiempo fue transformado por las acciones anticoloniales a las que Fanon le dedicaba su escritura. El eje principal de estos escritos fue demostrar que los seres humanos, particularmente aquellos demarcados por un sinnúmero de experiencias, tienen la capacidad de trascender en la construcción de otros significados. Esto es la capacidad humana, el explotar los límites para dar paso a la posibilidad humana.

\section{Referencias}


FANON, Frantz. Alienation and Freedom. Editado por Jean Khalfa y Robert Young. Trad. Steven Corcoran, Londres: Bloomsbury Academic, 2018.

FANON, Frantz. Piel negra, máscaras blancas. Trad. Iría Álvarez Moreno, Paloma Monleón Alonso y Ana Useros Martín. Madrid: Akal, 2009.

FANON, Frantz. Los condenados de la tierra. México: Fondo de Cultura Económica, 1963.

GIBSON, Nigel; ROBERTO Beneduce. Frantz Fanon, Psychiatry and Politics. Londres: Rowman and Littlefield, 2017.

GORDON, Jane Anna. Creolizing Political Theory: Reading Rousseau Though Fanon. Nueva York: Fordham University Press, 2014.

GORDON, Lewis R. Black Aesthetics, Black Value. Public Culture, v. 30, n. 1, p. 19-34, 2017. GIRDION, Lewis R. What Fanon Said: a philosophical introduction to his life and thought. New York: Fordham University Press, 2015.

MALDONADO TORRES, Nelson. Frantz Fanon and C.L.R. James on Intellectualism and Enlightened Rationality. Caribbean Studies, v. 33, n. 2, p. 149-194, jun.-dic., 2005. 